\title{
ERRORS IN THE ESTIMATION OF STREPTOMYCIN IN SERUM
}

\author{
BY \\ D. A. MITCHISON,* H. D. HOLT, AND S. H. MOORE \\ From the Postgraduate Medical School of London and the Central Public Health Laboratory, Colindale
}

(RECEIVED For PUblication, JANUARY 25, 1949)

In the report on specific laboratory tests in streptomycin therapy of tuberculosis (Medical Research Council, 1948) a subcommittee of the Medical Research Council recommended two techniques for the estimation of streptomycin in serum. One of these was a method involving serial dilutions in a serum-glucose-phenol-red indicator system on a waxed slide, followed by incubation in capillary tubes. The other was an agar diffusion technique carried out in small diameter tubes. An attempt has been made to assess the errors involved in using these two techniques under laboratory conditions similar to those in which they will actually be used.

\section{Plan of Experiment}

During the past two years estimations of streptomycin in serum have been made at Colindale using the capillary tube technique, whereas at the Postgraduate School of London the agar diffusion method has been used. One of us (D.A.M.) prepared a series of thirty sera containing known quantities of streptomycin. Each serum was divided into two portions, one of which was sent to Colindale and assayed by the capillary tube technique (H.D.H.), and the other was assayed at the Postgraduate School of London by the agar diffusion method (S.H.M.). - At the beginning of the experiment it was agreed that the range of streptomycin concentrations should be between 4 and $50 \mu \mathrm{g}$. $/ \mathrm{ml}$., which is the usual range found in patients on intramuscular therapy. No other information about the experimental plan was communicated till the end of the experiment, and no comments were passed on the results obtained.

The thirty sera tested were prepared as follows. Serum was obtained from healthy people and from ambulant patients attending for a variety of complaints. None of them was being treated with any

\footnotetext{
* In receipt of a grant from the Medical Research Council.
}

form of chemotherapy. Serum from a different person was used for each specimen. The specimens were made up by adding appropriate quantities of an aqueous solution of streptomycin hydrochloride (Merck, Batch 594) containing $1,000 \mu \mathrm{g} . / \mathrm{ml}$. Portions of the same solution were used for preparing the standards at the Postgraduate School of London and at Colindale. Three specimens were prepared on the same day and estimated together. Estimations were done on ten different days over a period of a month. On every day one each of the specimens was made up within each of the subranges 4-8.99, 9-19.99, 20$50 \mu \mathrm{g} . / \mathrm{ml}$. Altogether there were thus ten specimens within each of these subranges. The concentrations within each subrange were selected at random from all possible concentrations using a table of random numbers. The labelling of the specimens was also strictly at random.

\section{Techniques}

Capillary Tube Method (Medical Research Council, 1948). - The indicator medium contained 1 part horse serum, 1 part 10 per cent glucose, 2 parts water, and phenol red as an indicator. To this was added sufficient of a 24-hour broth culture of Klebsiella pneumoniae III to make a dilution of 1 in 50 . Serial dilutions were made in drops of saline on waxed slides with a Pasteur pipette, and to each of these an equal volume of the indicator medium was added. Capillary tubes were filled from the drops and incubated horizontally with the ends unsealed for 24 hours at $37^{\circ}$ C. A standard containing $16 \mu \mathrm{g} . / \mathrm{ml}$. was prepared in horse serum and set up in the same way at the same time. The reading was determined by comparison with the standard.

Agar Diffusion Method (Mitchison and Spicer, 1949). - One per cent nutrient agar (Japanese) with a $p \mathbf{H}$ adjusted to 7.8-8.0 contained in 1-oz. screw-capped bottles was seeded with an 18-hour broth culture of Staphylococcus aureus (N.C.T.C. 7361), to make a final dilution of 1 in 1,000. The agar was distributed with a Pasteur pipette into a series of tubes 7 to $8 \mathrm{~cm}$. long, $3 \mathrm{~mm}$. in internal diameter, and sealed at one end. The sera were pipetted on to the tops of the agar columns. Standards were prepared in human 
serum containing 4 and $50 \mu \mathrm{g} . / \mathrm{ml}$. Six tubes were set up for each standard and four for each test serum. After 24 hours' incubation at $37^{\circ} \mathrm{C}$. the depth of the zone of inhibition is measured to the nearest $0.1 \mathrm{~mm}$. using the traversing millimetre scale of a microscope with a crosswire in the eye-piece. The average of the readings from each serum was squared. The square of the zone of inhibition was linearly related to the $\log$ of the streptomycin concentration. A graph was plotted, one axis being $\log _{10}$ streptomycin concentration and the other axis the square of the zone of inhibition. The two points given by the readings of the standards were plotted and a straight line drawn between them. From this line the $\log _{10}$ of the streptomycin concentration in the test sera could be read off.

TABLE I

RESULTS OF ASSAYS OF STREPTOMYCIN IN SERLM

\begin{tabular}{|c|c|c|c|}
\hline \multirow[b]{2}{*}{ Day } & \multirow{2}{*}{$\begin{array}{l}\text { True value } \\
(\mu \mathrm{g} . \mathrm{ml} .)\end{array}$} & \multicolumn{2}{|c|}{ Estimated value } \\
\hline & & $\begin{array}{l}\text { Capillary } \\
\text { tube method } \\
(\mu \mathrm{g} . / \mathrm{ml} .)\end{array}$ & $\begin{array}{l}\text { Agar diffusion } \\
\text { method } \\
(\mu \mathrm{g} . / \mathrm{ml} .)\end{array}$ \\
\hline 1 & $\begin{array}{r}8.79 \\
11.63 \\
26.74\end{array}$ & $\begin{array}{r}4 \\
16 \\
32\end{array}$ & $\begin{array}{r}8.9 \\
13.2 \\
23.4\end{array}$ \\
\hline 2 & $\begin{array}{r}7.85 \\
10.65 \\
20.16\end{array}$ & $\begin{array}{l}32 \\
11 \\
21\end{array}$ & $\begin{array}{r}7.2 \\
10.0 \\
17.3\end{array}$ \\
\hline 3 & $\begin{array}{r}5.50 \\
15.20 \\
48.48\end{array}$ & $\begin{array}{l}16 \\
20 \\
64\end{array}$ & $\begin{array}{r}4.7 \\
12.0 \\
47.9\end{array}$ \\
\hline 4 & $\begin{array}{r}8.90 \\
10.18 \\
21.34\end{array}$ & $\begin{array}{l}5.3 \\
11 \\
11\end{array}$ & $\begin{array}{r}8.0 \\
10.0 \\
20.9\end{array}$ \\
\hline 5 & $\begin{array}{r}4.48 \\
16.87 \\
45.49\end{array}$ & $\begin{array}{l}21 \\
43 \\
64\end{array}$ & $\begin{array}{r}4.8 \\
18.6 \\
53.7\end{array}$ \\
\hline 6 & $\begin{array}{r}6.33 \\
8.37 \\
20.01\end{array}$ & $\begin{array}{l}6 \\
8 \\
8\end{array}$ & $\begin{array}{r}8.3 \\
9.8 \\
22.4\end{array}$ \\
\hline 7 & $\begin{array}{r}7.50 \\
19.25 \\
44.92\end{array}$ & $\begin{array}{l}16 \\
32 \\
48\end{array}$ & $\begin{array}{r}7.4 \\
24.6 \\
72.4\end{array}$ \\
\hline 8 & $\begin{array}{r}4.14 \\
10.39 \\
37.47 \\
\end{array}$ & $\begin{array}{r}12 \\
8 \\
24\end{array}$ & $\begin{array}{r}4.5 \\
11.2 \\
37.2\end{array}$ \\
\hline 9 & $\begin{array}{r}4.22 \\
10.57 \\
42.52\end{array}$ & $\begin{array}{r}16 \\
8 \\
24\end{array}$ & $\begin{array}{r}4.1 \\
9.5 \\
45.7\end{array}$ \\
\hline 10 & $\begin{array}{r}8.83 \\
18.91 \\
43.50\end{array}$ & $\begin{array}{r}8 \\
16 \\
32\end{array}$ & $\begin{array}{r}8.1 \\
18.2 \\
45.7\end{array}$ \\
\hline
\end{tabular}

\section{Results}

Details of the results obtained are given i $\overrightarrow{\bar{m}}$ Table I. The results were converted into $\log 8$ value and the estimated values of streptomycio concentration were plotted against the true valuese (Figs. 1 and 2). A regression line of estimate on true values was calculated. From the resultg ing analysis the following information was. obtained :

1. A deviation of the mean of the estimatef readings from the mean of the true readings woul indicate a general tendency to either under- of overestimate the streptomycin concentrations. Ib neither of the methods was there a systematie tendency of this nature.

2. The regression coefficients were tested for deviations from 1.0. There was no real difference in the case of the agar diffusion method (regrese sion co-efficient $1.04101 \pm 0.06370$ ). In the case of the capillary tube method the value found dif $\vec{\emptyset}$ fered significantly from 1.0 (regression coefficien $0.58485 \pm 0.14509$ ). This indicates a systematic error tending to overestimate low values and underestimate high values of streptomycin cons centration. Thus, apart from experimental varia tion, where the estimated value is $4 \mu \mathrm{g} . / \mathrm{ml}$., the true value will be about 69 per cent less, and where the estimated value is $50 \mu \mathrm{g} . / \mathrm{ml}$. the true valu $\vec{E}$ will be about 86 per cent greater.

3. An estimate of the error of both techniques. was obtained. The question requiring an answe is : At any estimated level of streptomycin concen? tration what are the limits within which the true value lies? For nineteen out of twenty assays the true value will lie within the fiducial limits tha? have been plotted in Figs. 1 and 2. Some representative values in numerical terms are given in Table II.

TABLE II

FIDUCIAL LIMITS OF TRUE VALUFS

\begin{tabular}{|c|c|c|}
\hline $\begin{array}{l}\text { Estimated } \\
\text { value } \\
\mu \mathrm{g} . / \mathrm{ml} .\end{array}$ & $\begin{array}{l}\text { Agar diffusion } \\
\text { method } \\
\mu \mathrm{g} . / \mathrm{ml} .\end{array}$ & $\begin{array}{l}\text { Capillary } \\
\text { tube method } \\
\mu \mathrm{g} . / \mathrm{ml} .\end{array}$ \\
\hline $\begin{array}{r}50 \\
32 \\
16 \\
8 \\
4\end{array}$ & $\begin{array}{c}63-34 \\
41-22 \\
21-11 \\
11-5.7 \\
6.0-2.8\end{array}$ & $\begin{array}{l}737-11.7 \\
343-5.5 \\
115-1.84 \\
32-0.58 \\
9.8-0.15\end{array}$ \\
\hline
\end{tabular}


Fig. 1.-Agar Diffusion Method. The $\log _{10}$ of the estimated values of the streptomycin soncentration have been plotted against the $\log _{10}$ of the true values. A regression line has been fitted to the points and the fiducial limits $(\mathbf{P}=$ 0.05) for the true values plotted. The vertical lines represent the streptomycin concentration in the two standards used.

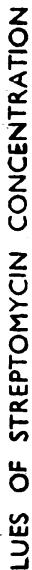

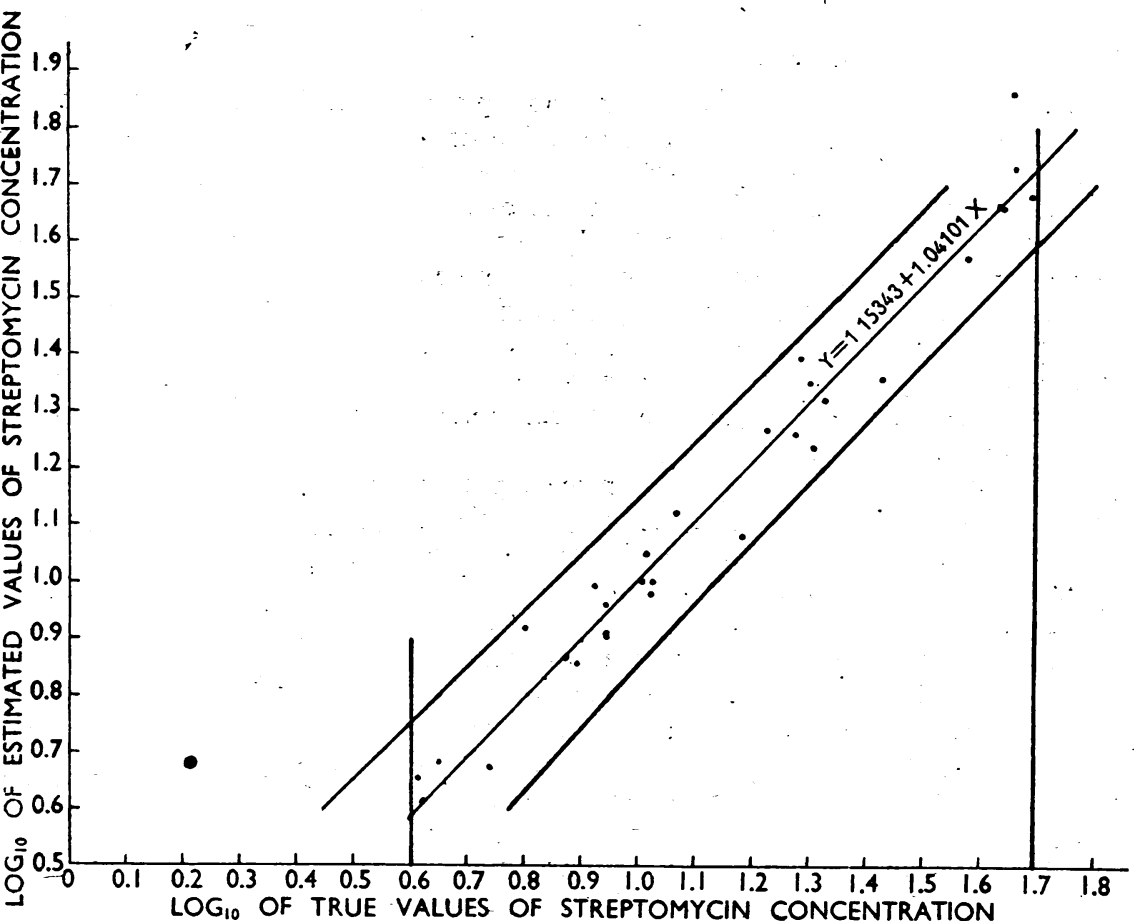
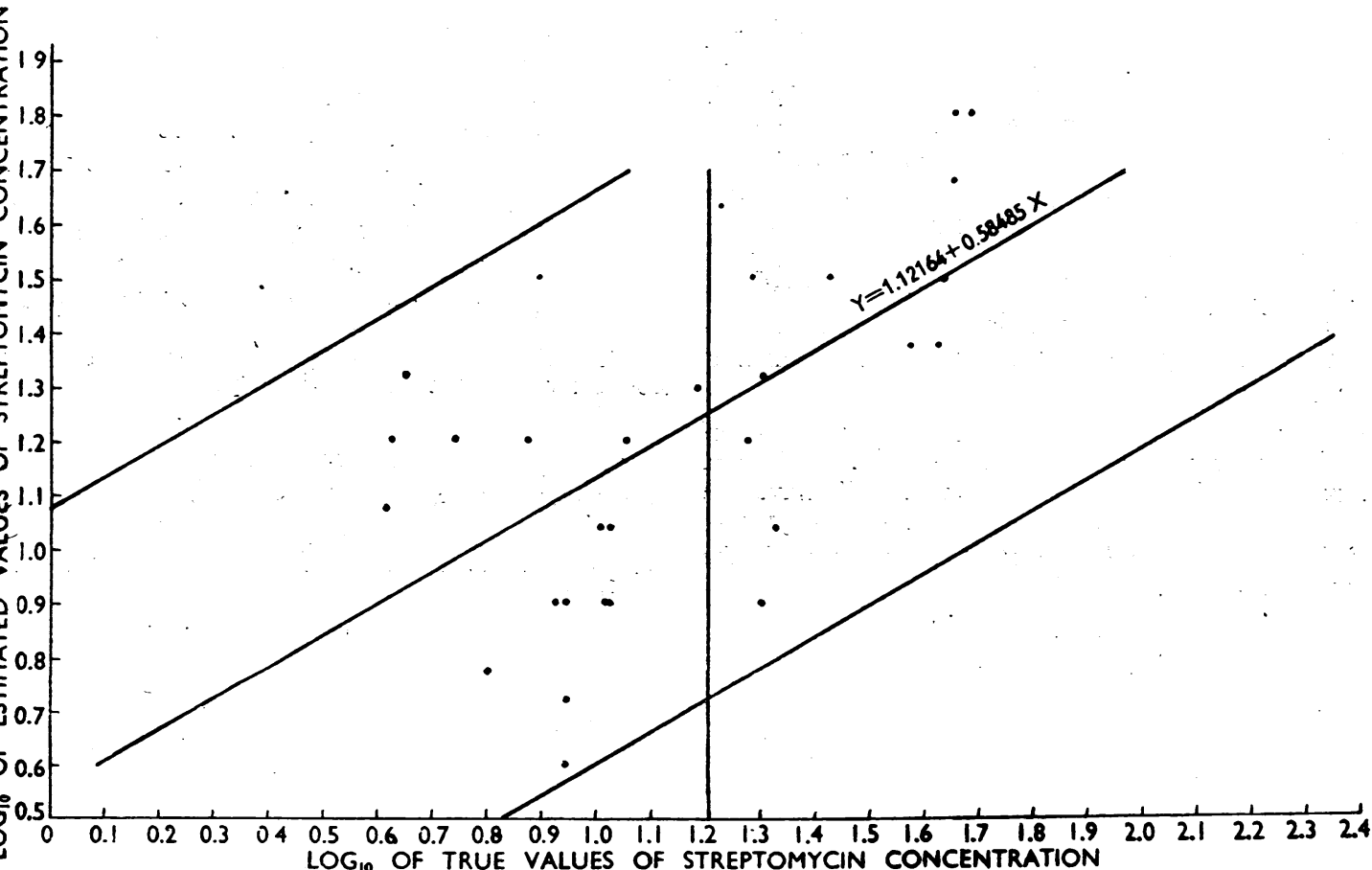

Fig.2.-Capillary Tube Method. The $\log _{10}$ of the estimated values of the streptomycin concentration have been plotted against the $\log _{10}$ of the true values. A regression line has been fitted to the points and the fiducial limits $(P=0.05)$ for the true values plotted. The vertical line represents the streptomycin concentration in the standard used. 


\section{Discussion}

From internal evidence (Mitchison and Spicer, 1949) the standard error (in logarithm units) of a typical assay using the agar diffusion technique was given as \pm 0.0422 . Owing to the use of sera derived from different individuals this figure should be multiplied by 1.73 , resulting in an estimated standard error of \pm 0.0730 . This figure is in good agreement with the estimates of the standard error obtained in this experiment. For instance at the mean of the estimated values the standard error was \pm 0.0660 .

It is clear that the errors involved in the capillary tube method are very large, and are particularly great when the readings on the test and control differ by more than one or two tubes. It might be advisable to set up standards at more than one streptomycin concentration with the test sera to be assayed. Even so the result of one estimation alone is highly unreliable. In view of the systematic tendency to underestimate high values and overestimate low values, even numerous readings will give fallacious answers unless several different standards are set up. The reasons for this systematic error are not clear. May and others (1947) indicate that organisms are inhibited by a higher concentration of streptomycin when serum water is diluted in saline. In the technique used here, serum dilutions are made in saline so that proportion of serum in the drops falls with each successive dilution. This might explain our findings. It might be advisable to carry out a similar experiment diluting the test serum in normal serum rather than in saline, in which case the composition of each drop would be constant. We feel that it is important that an estimate of error should be made of any new technique of assay which is tried.

Notes on the Statistical Analysis.-Let the $\log _{10}$ of the true values be $x$ and of the estimated values $y$. A regression line fitted to the values will have the form $y=\bar{y}+b(x-\bar{x})$. For the two sets of data we have, where $s_{i}$ is the standard error of $i$, the results shown in Table III.
TABLE III

STATISTICAL ANALYSIS OF CAPILLARY TUBE AND AGAR DIFFUSION METHODS

\begin{tabular}{|c|c|c|c|c|c|}
\hline & & & & $\begin{array}{c}\text { Capillary } \\
\text { tube } \\
\text { method }\end{array}$ & $\begin{array}{l}\text { Agar } \frac{\omega}{\sqrt{0}} \\
\text { diffusior } \\
\text { methodo }\end{array}$ \\
\hline $\bar{x} \quad \ldots$ & .. & .. & . & 1.14257 & $1.14257 \overrightarrow{0}$ \\
\hline $\bar{y} \quad \ldots$ & .. & .. & .. & 1.21640 & 1.15343 \\
\hline$s_{y}^{2} \ldots$ & .. & .. & .. & 0.065896 & 0.00405 \\
\hline$s_{x} \ldots$ & . & .. & .. & \pm 0.04687 & $\pm 0.0116 \widehat{3}$ \\
\hline$b \quad \ldots$ & . & .. & . & 0.58485 & $1.04101 \mathrm{~N}$ \\
\hline$s_{b} \quad \ldots$ & & & . & \pm 0.14509 & $\pm 0.0637 \alpha^{\omega}$ \\
\hline Deviatic & of & rom 1.0 & $t$ & 2.861 & $0.842 \vec{\omega}$ \\
\hline 28 degr & $s$ of & edom & $\mathbf{P}$ & $0.01-0.001$ & $0.5-0.4$ 윽 \\
\hline Deviatic & of & $\operatorname{rom} \bar{x}$ & $t$ & 1.575 & 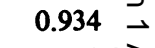 \\
\hline 28 degre & s of & edom & $\mathbf{P}$ & $0.2-0.1$ & $0.4-0.3 \underset{\Xi}{\mathbb{Q}}$ \\
\hline
\end{tabular}

The fiducial limits for $x$ were calculated from

$$
s_{x}^{2}=\frac{s_{y}^{2}}{b^{2}}+\frac{(y-\bar{y})^{2} s_{b}^{2}}{b^{4}}
$$

\section{Summary}

Known concentrations of streptomycin within their range $4-50 \mu \mathrm{g} . / \mathrm{ml}$. were made up in 80 specimens of serum and assayed by a capillaty tube technique and an agar diffusion technique. The capillary tube technique was shown to underestimate high concentrations of streptomycin apapd overestimate low concentrations. Fiducial limits of the true concentration expected from any estimated value within this range have been calculateg.

We wish to thank Dr. C. C. Spicer for adviceğin connexion with the statistical analysis.

\section{REFERENCES}

May, J. R., Voureka, A. E., and Fleming, A. (1947). Brit. med. J 627.

Medical Research Council (1948). Lancet, $2,862$.

Mitchison, D. A., and Spicer, C. C. (1949). J. gen. Microbiol. N3, 2,20 . 